\title{
Animal model show physiological characteristics can alter by feeding of different cereal type and exogenous multi-enzyme
}

\author{
Majid Kalantar ${ }^{1,2, a *}$ and Akbar Yaghobfar ${ }^{3, b}$ \\ ${ }^{1}$ Department of Animal Science, Qom's Agriculture and Education Research Center, Agricultural \\ Research, Education and Extension Organization, IR Iran, P.O Box: 195 \\ 2 Department of Animal Science, Agricultural Faculty, Shahrekord University, Shahrekord, \\ IR Iran,P.O. Box: 165 \\ ${ }^{3}$ Department of Poultry Nutrition and Physiology, Animal Science Research Institute, Karaj, \\ IR Iran, P.O. Box: 1383 \\ am2332012@gmail.com, byaghobfar@yahoo.com
}

Keywords: Animal model, Physiological characteristic, Cereal type, exo-enzyme.

\begin{abstract}
Physiological characteristics of meat-type chicken such as growth traits, serum biochemical metabolites and mineral concentrations, serum enzyme activity, and gut flora were studied by means of 625 day-old chicks which randomly assigned to five treatments with five replicates in a completely randomized design. Four different types of cereal-based diets (wheat, and barley with or without exogenous multi-enzyme supplement) were used as experimental groups and a corn-based diet was also considered to serve as control group. All diets had similar contents of crude protein, energy, and total non-starch polysaccharides (NSP). Results indicated that enzyme supplemented diets improved daily weight gain and feed conversion ratio than barley and wheat diets without enzyme significantly $(\mathrm{P}<0.01)$. Feeding wheat and barley diets decreased the serum cholesterol, triglyceride and glucose concentrations than control group significantly $(\mathrm{P}<0.01)$. Also using of these two type of cereals without enzyme supplementation resulted in reduced serum mineral concentration and undesirable effect on gut flora $(\mathrm{P}<0.01)$. Total gram negative bacteria of the ileum was decreased, however lactic acid and bifida bacteria population were increased by supplementation of wheat and barley diets with exogenous multi-enzyme significantly $(\mathrm{P}<0.01)$. The serum activities of $\alpha$-amylase and lipase were increased in chicks fed wheat and barley diets when compared to the control group fed on corn diet, but enzyme supplementation significantly reduced the serum activities of $\alpha$-amylase and lipase $(\mathrm{P}<0.01)$.
\end{abstract}

\section{Introduction}

Alternative grains can be successfully replaced for corn in poultry diets. Wheat and barley are generally used as major sources of energy in poultry diets. Though the major components of these grains are starch and proteins, they have considerable content of non-starch polysaccharides (NSPs), derived from the cell walls [15,17]. NSPs are generally considered as anti-nutritional factors [7]. The content and structure of NSP polymers vary between different grains, which consequently affect their nutritive value and anti-nutritional impacts [17]. The major part of NSPs of wheat is constituted by arabinoxylan polymers, whereas NSPs in barley comprises polymers of $\beta$-glucans $[3,7,24]$. A review of literature indicates that a complex blend of exogenous multienzyme is required to degrade the NSPs present in the diet in order to obtain satisfactory health, performance and nutrient digestibility through the gut $[11,17,18,22]$. Few researches have shown the magnitude of adverse effect of equal fractions of NSP from different sources. Besides, there is limited information on the efficacy of multi-enzyme supplements under such circumstances. In the present study, equal fractions of NSP from wheat and barley were included in chicken diets with and without exogenous multi-enzyme to compare the negative effects on growth, serum concentration of metabolites and minerals, intestinal bacterial population, and serum enzyme activity of $\alpha$-amylase and lipase compared to corn-based diet. 


\section{Materials and Methods}

\subsection{Animals, management and treatments}

A total number of 625 day-old broiler chickens (Ross-308 strain) were randomly assigned to five treatments and five replicates of 25 chicks each. Each replicate was a floor pen of $1.5 \times 2.2 \mathrm{~m}^{2}$. Five experimental diets based on corn $(\mathrm{C})$, wheat (W), barley (B), wheat +exo-enzyme (WE) and barley +exo-enzyme (BE) were formulated for birds according to NRC recommendations [16]. The enzyme supplement $\left(\mathrm{COMBO}^{\circledR}\right.$ enzyme blend) contained $480 \mathrm{U} / \mathrm{g}$ multi-glycanase (including 200 $\mathrm{U} / \mathrm{g}$ xylanase, $200 \mathrm{U} / \mathrm{g} \beta$-glucanase, and $80 \mathrm{U} / \mathrm{g}$ hemi-cellulase) and $1000 \mathrm{U} / \mathrm{g}$ phytase which used at level of $1 \mathrm{~g} / \mathrm{kg}$ in the experimental diets. Wheat and barley samples were analyzed based on A.O.A.C instructions [1] before the experiment for non-starch polysaccharide constituents, which depicted in Table 1. All cereal-based diets were formulated to have equal fractions of soluble NSP.

Table 1. Non-starch polysaccharide constituents of wheat and barley samples before

\begin{tabular}{|c|c|c|c|c|c|c|c|}
\hline Sample & Cellulose $^{1}$ & $\begin{array}{l}\text { Hemi- } \\
\text { Cellulose }\end{array}$ & $\begin{array}{l}\text { Lignin }^{3} \\
(\mathrm{ADL})\end{array}$ & Total NSP & $\begin{array}{l}\text { Soluble } \\
\text { NSP } \\
\end{array}$ & Insoluble NSP & $\mathrm{DF}^{4}$ \\
\hline $\begin{array}{l}\text { Wheat } \\
( \pm \mathrm{SE})\end{array}$ & $\begin{array}{l}1.8 \\
( \pm 0.1)\end{array}$ & $\begin{array}{l}10.4 \\
( \pm 0.52)\end{array}$ & $\begin{array}{l}1.59 \\
( \pm 0.18)\end{array}$ & $\begin{array}{l}13.11 \\
( \pm 0.64)\end{array}$ & $\begin{array}{l}.45 \\
( \pm 0.12)\end{array}$ & $\begin{array}{l}10.66 \\
( \pm 0.53)\end{array}$ & $\begin{array}{l}14.7 \\
( \pm 0.73)\end{array}$ \\
\hline $\begin{array}{l}\text { Barley } \\
( \pm \text { SE })\end{array}$ & $\begin{array}{l}4.4 \\
( \pm 0.24)\end{array}$ & $\begin{array}{l}23.62 \\
( \pm 1.42)\end{array}$ & $\begin{array}{l}1.97 \\
( \pm 0.24)\end{array}$ & $\begin{array}{l}16.73 \\
( \pm 0.81)\end{array}$ & $\begin{array}{l}4.12 \\
( \pm 0.15)\end{array}$ & $\begin{array}{l}12.61 \\
( \pm 0.65)\end{array}$ & $\begin{array}{l}18.7 \\
( \pm 0.94)\end{array}$ \\
\hline
\end{tabular}

1: Cellulose $=$ ADF-ADL 2: Hemi-Cellulose=NDF-ADF 3: Lignin (ADL) $=$ ADF-Cellulose 4: Dietary Fiber=Total NSP +ADL.

Feed and water were provided at free access. Environmental conditions including temperature and lighting schedule followed the management guideline of the Ross-308 strain. The experimental animals were kept, maintained and treated in accepted standards for the human treatment of animals.

\subsection{Measurements}

Feed intake, weight gain, and feed conversion ratio (FCR) was calculated as daily mean values. On 42 days of ages, 3 birds from each replicate were randomly selected and blood samples were taken from wing vein, blood samples were transferred to vial tubes containing sodium heparin. The tubes were centrifuged at $5000 \times \mathrm{g}$ for $20 \mathrm{~min}$, and the supernatant was discarded. Serum glucose, cholesterol, triglyceride and mineral concentrations ( $\mathrm{Ca}, \mathrm{P}, \mathrm{Mg}$, and $\mathrm{Zn}$ ) were measured by use of specific kits (Biosystem Company, Spain). Also the harvested serum was used for serum enzyme assay. The serum activity of $\alpha$-amylase (EC 3.2.1.1) was determined using a validated kit from Parsazmun Chemical Company (Parsazmun Co., Karaj, Iran) and the serum activity of lipase (EC 3.1.1.3) was measured by a validated kit from ZiestChem Chemical Company (ZiestChem Co., Tehran, Iran) according to the manufacturer's instructions. The activities of $\alpha$-amylase and lipase are expressed as International Unit (IU) per one liter of serum $[9,10]$.

At the day of 42 , three chicks per pen (15 chickens from each treatment) were randomly selected and killed by decapitation. Intestinal micro-biota was enumerated according to Langhout et al. (1999) with some modification [12]. In brief, aqueous digesta samples (3 ml) were taken from the distal segment of ileum and immediately transferred to sterile bottles containing $15 \mathrm{ml}$ anaerobic transport medium (TRM; $\mathrm{pH}$ 7.0). The samples were weighted and stored at $4 \mathrm{oC}$ for further examination. Samples were homogenized and $1 \mathrm{ml}$ of each sample serially diluted 10- fold. An aliquot $(0.1 \mathrm{ml})$ of each diluted sample was then cultivated on specific media and transferred to an incubator set at $37 \mathrm{oC}$ for 24 hours. At the end of incubation period, bacterial colonies were counted. Specific media as described below were used to culture different type of bacteria including Eosin Methylene Blue (EMB) Agar for Gram negative bacteria, Rogosa Agar (RA) for lactic acids, and Eugon Agar (EA) for bifida bacteria, respectively [9,10]. 


\subsection{Statistical procedures}

The results were statistically analyzed by GLM procedure of SAS software of SAS Institute Inc [21]. Statistical scheme was based on completely randomized design (CRD). Samples within pens (3 per each unit) were subjected to nested analysis. Duncan's multiple range tests was used to separate the means.

\section{Results}

\subsection{Growth performance}

Table 2 depicts the daily mean results of feed intake, weight gain, and feed conversion ratio of chickens throughout the trial. Results indicated that birds fed wheat significantly $(\mathrm{P}<0.01)$ reduced their feed intake compared to other groups. Supplementing exogenous multi-enzyme to the wheat diet remarkably restored feed intake so that the difference was not significant with the control fed on corn. On the other hand, birds fed barley had numerically higher feed intake than other treatments. Supplementing the barley diet with exogenous multi-enzyme significantly $(\mathrm{P}<0.01)$ increased feed intake compared to the wheat and corn diets. Nevertheless, birds fed on barley and wheat diets had significantly lower body weight and higher feed conversion ratio (FCR) than their counterparts fed on corn or enzyme supplemented diets $(\mathrm{P}<0.01)$.

Table 2. Effect of different type of cereal grains and enzyme supplementation on growth traits of

\begin{tabular}{lccc}
\multicolumn{3}{c}{ chickens. } \\
\hline Treatments & $\begin{array}{c}\text { Daily feed intake } \\
{[\mathrm{g} / \mathrm{bird}]}\end{array}$ & $\begin{array}{c}\text { Daily weight gain } \\
{[\mathrm{g} / \mathrm{bird}]}\end{array}$ & $\begin{array}{c}\text { Feed conversion ratio } \\
{[\mathrm{FCR}]}\end{array}$ \\
\hline $\mathrm{C}$ & $101.90^{\mathrm{b}}$ & $53.60^{\mathrm{a}}$ & $1.90^{\mathrm{c}}$ \\
$\mathrm{W}$ & $99.14^{\mathrm{c}}$ & $47.98^{\mathrm{b}}$ & $2.06^{\mathrm{a}}$ \\
$\mathrm{WE}$ & $101.26^{\mathrm{b}}$ & $50.45^{\mathrm{b}}$ & $2.00^{\mathrm{b}}$ \\
$\mathrm{B}$ & $103.17^{\mathrm{a}}$ & $50.17^{\mathrm{b}}$ & $2.05^{\mathrm{a}}$ \\
$\mathrm{BE}$ & $104.57^{\mathrm{a}}$ & $52.36^{\mathrm{ab}}$ & $1.99^{\mathrm{b}}$ \\
$\mathrm{SEM}$ & 0.56 & 0.53 & 0.02 \\
\hline$*^{\mathrm{abc}}$ Means with different superscript letters within columns have significant difference \\
(P<0.01). ${ }^{*}$ C:corn, W:wheat, B:barley, WE:wheat+enzyme, BE:barley+enzyme. \\
\hline
\end{tabular}

\subsection{Serum biochemical metabolites and mineral concentrations}

Table 3 and table 4 depicts the mean changes of serum biochemical metabolites and mineral concentrations of chickens after feeding of wheat and barley with or without enzyme supplement compared to control group.

Table 3. Effect of different type of cereal grains and enzyme supplementation on serum metabolite concentrations of chickens [mg/dl].

\begin{tabular}{lccc}
\hline Treatments & Cholesterol & Triglyceride & Glucose \\
\hline $\mathrm{C}$ & $135^{\mathrm{a}}$ & $131^{\mathrm{a}}$ & $270^{\mathrm{a}}$ \\
$\mathrm{W}$ & $116^{\mathrm{c}}$ & $116^{\mathrm{c}}$ & $216^{\mathrm{c}}$ \\
$\mathrm{WE}$ & $125^{\mathrm{b}}$ & $121^{\mathrm{b}}$ & $252^{\mathrm{b}}$ \\
$\mathrm{B}$ & $114^{\mathrm{c}}$ & $115^{\mathrm{c}}$ & $201^{\mathrm{c}}$ \\
$\mathrm{BE}$ & $122^{\mathrm{b}}$ & $119^{\mathrm{b}}$ & $241^{\mathrm{b}}$ \\
SEM & 1.52 & 1.22 & 6.42 \\
\hline *abc Means with different superscript letters $^{\mathrm{b}}$ within columns have significant \\
difference (P<0.01). ${ }^{1} \mathrm{U} /$ Lit: Units of enzymes (IU) per one liter of serum. \\
${ }^{*}$ C:corn, W:wheat, B:barley, WE:wheat+enzyme, BE:barley+enzyme. \\
\hline
\end{tabular}

Results indicated that birds fed wheat or barley significantly $(\mathrm{P}<0.01)$ reduced their serum metabolites and mineral concentration compared to other groups. Supplementing exogenous multienzyme to the wheat or barley diet remarkably restored the situation so that the differences were not significant than their counterpart fed on corn. On the other hand, birds fed wheat or barley had numerically lower serum metabolites and mineral concentration than other treatments. 
Table 4. Effect of different types of cereal grains and enzyme supplementation on broiler serum mineral concentrations of chickens $[\mathrm{mg} / \mathrm{dl}]$.

\begin{tabular}{lcccc}
\hline Treatments & $\mathrm{Ca}$ & $\mathrm{P}$ & $\mathrm{Mg}$ & $\mathrm{Zn}$ \\
\hline $\mathrm{C}$ & $135^{\mathrm{a}}$ & $131^{\mathrm{a}}$ & $270^{\mathrm{a}}$ & $270^{\mathrm{a}}$ \\
$\mathrm{W}$ & $116^{\mathrm{c}}$ & $116^{\mathrm{c}}$ & $216^{\mathrm{c}}$ & $216^{\mathrm{c}}$ \\
$\mathrm{WE}$ & $125^{\mathrm{b}}$ & $121^{\mathrm{b}}$ & $252^{\mathrm{b}}$ & $252^{\mathrm{b}}$ \\
$\mathrm{B}$ & $114^{\mathrm{c}}$ & $115^{\mathrm{c}}$ & $201^{\mathrm{c}}$ & $201^{\mathrm{c}}$ \\
$\mathrm{BE}$ & $122^{\mathrm{b}}$ & $119^{\mathrm{b}}$ & $241^{\mathrm{b}}$ & $241^{\mathrm{b}}$ \\
$\mathrm{SEM}$ & 1.52 & 1.22 & 6.42 & 6.42 \\
\hline *abc Means with different superscript letters within columns have significant difference $^{\text {(P<0.01). }}{ }^{1} \mathrm{U} /$ Lit: Units of enzymes (IU) per one liter of serum. \\
${ }^{*}$ C:corn, W:wheat, B:barley, WE:wheat+enzyme, BE:barley+enzyme. \\
\hline
\end{tabular}

\subsection{Intestinal microbial}

According to the results of table 5, total counts of Gram negative bacteria including E. coli and clostridia in the intestinal content were higher in birds fed wheat and barley than the control $(\mathrm{P}<0.01)$. On the other hand, the number of lactic acid bacteria and bifid bacteria were significantly lower $(\mathrm{P}<0.01)$ in birds received wheat and barley diets compared to the control. Inclusion of an exogenous multi-enzyme supplement to the wheat and barley diets modified the situation so that no significant difference was found between the wheat and barley diets supplemented with the enzyme supplemented and the corn diet.

Table 5. Effect of different types of cereal grains and enzyme supplementation on intestinal bacterial population of chickens [log CFU/g digesta]

\begin{tabular}{lccc}
\hline Treatments & Total gram negative & Lactic acid bacteria & Bifida bacteria \\
\hline $\mathrm{C}$ & $5.31^{\mathrm{b}}$ & $4.90^{\mathrm{b}}$ & $5.40^{\mathrm{b}}$ \\
$\mathrm{W}$ & $6.33^{\mathrm{a}}$ & $3.87^{\mathrm{c}}$ & $4.06^{\mathrm{c}}$ \\
$\mathrm{WE}$ & $5.21^{\mathrm{bc}}$ & $5.19^{\mathrm{a}}$ & $5.67^{\mathrm{a}}$ \\
$\mathrm{B}$ & $6.24^{\mathrm{a}}$ & $4.90^{\mathrm{b}}$ & $3.51^{\mathrm{d}}$ \\
$\mathrm{BE}$ & $5.26^{\mathrm{b}}$ & $5.40^{\mathrm{a}}$ & $5.76^{\mathrm{a}}$ \\
$\mathrm{SEM}$ & 0.13 & 0.10 & 0.11 \\
\hline * $^{\mathrm{abc}}$ Means with different superscript letters within columns have significant difference \\
(P<0.01). ${ }^{1} \mathrm{U} /$ Lit: Units of enzymes (IU) per one liter of serum. *C:corn, W:wheat, B:barley, \\
WE:wheat+enzyme, BE:barley+enzyme.
\end{tabular}

\subsection{Serum enzyme activity}

Based on results depicted in table 6, Serum enzyme activity of chickens fed wheat and barley were significantly $(\mathrm{P}<0.01)$ increased compared to the control group fed on corn. Supplementation of exogenous multi-enzyme mixture to the wheat and barley diets significantly reduced the serum enzyme activity of $\alpha$-amylase and lipase.

Table 6. Effect of different types of cereal grains and enzyme supplementation on serum enzyme activity of chickens

\begin{tabular}{|c|c|c|}
\hline \multirow[t]{2}{*}{ Treatments } & \multicolumn{2}{|c|}{ 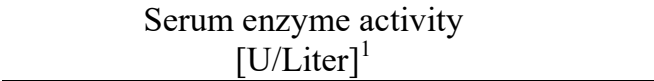 } \\
\hline & $\alpha$-amylase & Lipase \\
\hline $\mathrm{C}$ & $22.94^{\mathrm{c}}$ & $10.24^{\mathrm{c}}$ \\
\hline W & $60.48^{\mathrm{ab}}$ & $21.83^{\mathrm{a}}$ \\
\hline WE & $49.48^{b}$ & $17.62^{\mathrm{b}}$ \\
\hline B & $66.32^{\mathrm{a}}$ & $20.84^{\mathrm{a}}$ \\
\hline $\mathrm{BE}$ & $47.71^{\mathrm{b}}$ & $18.72^{\mathrm{ab}}$ \\
\hline SEM & 2.60 & 1.31 \\
\hline \multicolumn{3}{|c|}{$\begin{array}{l}{ }^{* a b c} \text { Means with different superscript letters within columns have } \\
\text { significant difference }(\mathrm{P}<0.01) .{ }^{1} \mathrm{U} / \text { Lit: Units of enzymes (IU) per } \\
\text { one liter of serum. }{ }^{*} \mathrm{C}: \text { corn, W: wheat, B:barley, WE: wheat+enzyme, } \\
\text { BE:barley+enzyme. }\end{array}$} \\
\hline
\end{tabular}




\section{Discussion}

Soluble fraction of non-starch polysaccharides (NSP) have a highlight negative effect on growth and other physiological characteristics of chickens due to impairment of gut efficiency by different cereals cell wall constituents $[15,17,24]$. However, the comparative effects of the cereal type and structure of NSP on growth and physiological response have not been adequately addressed. Results reported herein indicate that pentosan polymers of wheat's NSP have more deleterious impact on voluntary feed intake of broiler chickens than $\beta$-glucans polymers of barley's NSP. Birds fed on wheat diet consumed lower feed and consequently lower body weight gain compared to those fed barley, primarily due to their differences in NSP constituent resulted in increased digesta viscosity in the intestine [9].

Increased viscosity per se creates ideal environment for maximal proliferation of anaerobic and Gram negative bacteria as observed in this study. These observations are in line with other reports $[8,12]$. According to the results of one research, slow movement of digesta and low oxygen condition due to the presence of NSP provide a stable media, where fermentative microbes such as anaerobic bacteria proliferate easily [12]. Such microbial changes reduce nutrients available for host and produce detrimental by-products [4]. Water soluble NSPs of wheat were reported to have deleterious impact on physicochemical properties and microbial proliferation of digesta in the intestinal tract of chickens $[3,4]$. Results of this experiment also indicate that NSP polymers of wheat and barley decreased the population of lactic acid bacteria and Bifida bacteria in the intestinal digesta (table 5). These bacteria are associated with beneficial effects to birds and are known as probiotics growth promoters. Impaired live performance of birds fed on wheat and barley can partly be explained by decrease in population of Gram positive bacteria including Lactobacilli and Bifida bacteria. The probiotic-type bacteria modulate innate immune system of the host [5], and they are necessary for the development of gut-associated lymphoid tissue (GLUT) [19].

Supplementation of wheat and barley diets with exogenous multi-enzyme significantly reduced the negative effects of NSP on proliferation of useful bacteria through breakdown of NSP polymers. These results are in accordance with relevant reports. [4,15,24]. Degrading NSP enzymes including xylanases and $\beta$-glucanases release the encapsulated nutrients and reduce digesta viscosity which facilitated by the further action of phytase $[17,18]$.

According to results presented in table 3, reduced cholesterol, triglyceride and glucose can resulted from increase of dietary fiber content of wheat and barley in company with NSP and related digesta viscosity which leads to quick changes in the intestinal passage rate and dynamic of digestion and absorption of nutrients due to impaired physico-chemical properties of the intestinal content [20]. Therefore, it is concluded that the lower serum concentrations of biochemical metabolites and minerals induced by wheat and barley diets are related to their dietary fiber and NSP content. Decreased serum concentrations of metabolites and minerals is associated with reduction in intestinal absorptive potential due to impaired nutrient transporters at gut wall, impede digestive enzyme and normal physiological responses [9,10,20].

Serum $\alpha$-amylase and lipase activities of chickens were significantly increased in birds fed on wheat and barley diets as compared to those fed on corn diet or wheat and barley diets supplemented with enzyme cocktail. This finding reflects the fact that water soluble NSP of wheat and barley impede pancreatic $\alpha$-amylase and lipase activities, as well as intestinal enzyme secretory organs which further resulted in enzyme leakage into serum [13]. This finding may indicate needs for greater secretion of enzymes due to increased contents of NSP inside the gut and increased substrate levels through the serum that induced high concentration of enzymes $[6,23]$. Research has shown that intestinal or serum enzyme activity depends on dietary nutrient source and presence of anti-nutrients in the gut $[13,15]$. Also diet type affects the rate of enzyme secretion. Diets with high fat or carbohydrates increase the secretion rate and serum concentration of amylase and lipase $[2,14,25]$. Amylase is secreted in saliva, intestinal fluid, and pancreatic juices. As well as lipase is secreted in stomach and pancreatic juices [2]. In normal conditions, pancreas-derived amylase and lipase makes up only a small portion of serum enzymes, but with abnormal conditions such as 
change in diet cereal type and high amount of anti-nutritional factors, acute pancreatitis and leakage of enzymes, total serum concentration of mentioned enzymes rise significantly [23].

\section{Conclusion}

According to the results of the present study NSP solubility of different type of cereals and its contribution to produce high viscose digesta play an important role in chicken growth efficiency and physiological response. In conclusion, various NSP components of wheat and barley have adverse effects on serum concentration of biochemical metabolites, minerals, and population of benefit bacteria. Besides, NSP polymers of wheat and barley increase the serum activities of $\alpha$ amylase and lipase. These deleterious impacts could restore by supplementing exogenous multienzymes to chicken diets.

\section{Acknowledgment}

Authors appreciate financial support of the Animal Research Institute, Karaj, Iran and Shahrekord University, Shahrekord Iran.

\section{References}

[1] Association of Official Analytical Chemists (A.O.A.C). Official Methods of Analysis of the Association of Analytical Chemists International, 18th ed., 1st suppl. Gaithersburg, MD U.S.A, 2005.

[2] A. Brenes, M. Smith, W. Guener, and R.R. Marquardt, Effect of enzyme supplementation on the performance and digestive tract size of broiler chickens fed wheat and barley based diets. J. Poult. Sci. 72(1993a) 1731-1739.

[3] M. Choct, Feed non-starch polysaccharides: Chemical structures and nutritional significance. J. Feed. Mill. Inter. June Issue. (1997) 13-26.

[4] M. Choct, M. Sinlae, R.A.M. Al-Jassim, and D. Pettersson, Effects of xylanase supplementation on between-bird variation in energy metabolism and the number of Clostridium perfringens in broilers fed a wheat-based diet. Aust. J. Agric. Res. 57 (2006) 1017-1021.

[5] H.R. Christensen, H. Frokiar, and J.J. Pestka, Lactobacilli differentially modulate expression of cytokines and maturation surface markers in murine dendritic cells. J. Immunol. 168(2002) 171178.

[6] D. M. Denbow, Gastrointestinal anatomy and physiology. In: Sturkie's avian physiology, 5th ed. Academic Press, San Diego, 2000.

[7] D. Jamroz, K. Jacobsen, K. E. Bach Knudsen, A. Wiliczkiewicz, and J. Orda, Digestibility and energy value of non-starch polysaccharides in young chickens, ducks and geese, fed diet containing high amount of barley. J. Comp. Biochem. Physiol. 131(2002) 657-668.

[8] D. Jaroni, S.E. Scheideler, M.M. Beck, and C. Wyatt, The effect of dietary wheat middling and enzyme supplementation. II: Apparent nutrient digestibility, digestive tract size, gut viscosity and gut morphology in two strains of leghorn hens. J. Poult. Sci. 78(1999) 1664-1674.

[9] M. Kalantar, M. Rezaei, J. Salari, and H.R. Hemati Matin, Thymus vulgaris L., Glycyrrhiza glabra or Combo ${ }^{\circledR}$ Enzyme in Corn vs. Barley-Based Broiler Diets. J. Coast. Life. Med. 2(2012) 993-997.

[10] M. Kalantar, F. Khajali, and A. Yaghofar, Different Dietary Sources of NSP Supplemented with Enzymes Affected Growth and Carcass traits, Blood Parameters and Gut Physiochemical properties of Broilers. Glob.J. Anim. Sci.Res. 3(2015): 412-418 
[11] F. Khajali, and B.A. Slominski, Factors that affect the nutritive value of canola meal for poultry. J. Poult. Sci. 91(2012) 2564- 2575.

[12] D.J. Langhout, J.B. Schutte, P. Van Leeuwen, J. Wiebenga, and S. Tamminga, Effect of dietary high-and low-methylated citrus pectin on the activity of the ileal micro flora and morphology of the small intestinal wall of broiler chicks. J. Br. Poult. Sci. 40(1999) 340-347.

[13] W.F. Li, J. Feng, Z.R. Xu, and C.M. Yang, Effects of non-starch polysaccharides enzymes on pancreatic and small intestinal digestive enzyme activities in piglet fed diets containing high amounts of barley. World. J. Gastroenterol. 10(2004) 856-859.

[14] P.H. Lin, B.I. Shih, and J.C. Hsu, Effects of different source of dietary non-starch polysaccharides on the growth performance, development of digestive tract and activities of pancreatic enzymes in goslings. J. Br. Poult. Sci. 51(2010) 270-277.

[15] S. Mirzaie, M. Zaghari, S, Aminzadeh, M. Shivazad, G.G. Mateos, Effect of wheat inclusion and xylanase supplementation of the diet on productive performance, nutrient retention and endogenous intestinal enzyme activity of laying hens. J. Poult. Sci. 91(2012) 413-425.

[16] National Research Council (N.R.C), Nutrient Requirements of Poultry. National Academy of Science. Washington, D. C, 1994.

[17] O.A. Olukosi, A. J. Cowieson, and O. Adeola, Age-related influence of a cocktail of xylanase, amylase, and protease or phytase individually or in combination in broilers. J. Poult. Sci. 86(2007) 77-86.

[18] V. Ravindran, P.H. Selle, and W.L. Bryden, Effects of phytase supplementation, individually and in combination, with glycanase, on the nutritive value of wheat and barley. J. Poult. Sci. 78(1999) 1588-1595.

[19] K.J. Rhee, P.J. Jasper, P. Sethupathi, N. Shanmugam, D. Lanning, and K.L. Knight, Positive selection of the peripheral B cell repertoire in gut-associated lymphoid tissues. J. Exp. Med. 201(2005) 55-62.

[20] A.A. Saki, H.R. Hematti Matin, P. Zamani, M.M. Tabatabai, and M. Vatanchian, Various ratios of pectin to cellulose affect intestinal morphology, DNA quantitation, and performance of broiler chickens. J. Live. Sci. 139(2011) 237-244.

[21] SAS Institute. SAS procedure guide for personal computers, STAT User Guide, Statistics. Version 9.1. SAS Institute INC, Cary NC, 2004.

[22] B.A. Slominski, Recent advances in research on enzymes for poultry diets. (Review), J. Poult. Sci. 90(2011) 2013-2023.

[23] D.A. Williams, The pancreas. In: Strombeck's small animal gastroenterology. 3rd ed. Saunders, Philadelphia, 1996.

[24] Y.L. Yin, S.K. Baidoo, and J.L.L. Boychuk, Effect of enzyme supplementation on the performance of broilers fed maize, wheat, barley or micronized dehulled barley diets. J. Anim. Feed. Sci. 9(2000) 493-504.

[25] F. Zhao, S.S. Hou, H.F. Zhang, and Z.Y. Zhang, Effects of dietary metabolizable energy and crude protein content on the activities of digestive enzymes in jejunal fluid of Peking ducks. J. Poult. Sci. 86(2007) 1690-1695. 